\title{
Bienvenidos a la nueva edición de la $\mathrm{RCHO}$
}

\section{Welcome to the new edition of the $\mathrm{RCHO}$}

\section{Pedro Ramos Guette}

La revista de la Asociación Colombiana de Hematología y Oncología (ACHO) fue creada por la iniciativa de Andrés Felipe Cardona; en un esfuerzo personal y heroico, se logró la publicación de siete números desde abril de 2012 hasta octubre de 2013, cuando se interrumpió por razones de fuerza mayor de índole personal del editor jefe. Ofrecemos excusas y esperamos que el proceso actual sea continuo y sin interrupciones.

En diciembre de 2015, se reinicia el proceso con el nombramiento del editor en jefe y la conformación del comité editorial, con la representación de todas las regiones del país y los programas de formación en hematología y oncología de todo el territorio nacional; se contrató la asesoría del Instituto para la Evaluación de la Calidad y Atención en Salud (IECAS), y se establecieron las políticas editoriales siguiendo las guías y normas para publicación del Comité Internacional de Editores de Revistas Médicas (ICMJE), que tratan de las responsabilidades de los autores, los asuntos editoriales, la preparación y envío de los manuscritos'.

El objetivo de la Revista Colombiana de Hematología y Oncología es la publicación de la investigación en dichas especialidades y otras áreas afines, para hacerla visible en el ámbito nacional e internacional.

Su visión es ser para 2020 la revista indexada en hematología y oncología más importante a nivel nacional.

Con el fin de lograr los requisitos mínimos para la indexación, la revista publicará cuatro volúmenes (edición trimestral) y al menos 12 artículos originales al año, tres por número. Cada número tendrá además una o más editoriales, casos clínicos, artículo de imágenes y las cartas al editor que se reciban. Ocasionalmente, se agregarán, bajo encargo del comité, artículos de revisión, de investigación o especiales, para lo cual requerimos la participación activa de todos los miembros de la ACHO para someter los manuscritos que tengan disponibles.

El editor jefe, como el líder del proceso editorial, con la valiosa ayuda del comité editorial, promoverá la comunicación clara y cordial entre los autores y los integrantes de la revista para lograr los objetivos trazados.

Los miembros del comité editorial son asesores estratégicos, editores asociados de manuscritos sometidos, pares evaluadores en los artículos en los cuales no sean editores, autores ocasionales, veedores del proceso editorial y promotores de la revista, con el fin de atraer autores, lectores y evaluadores.

La revista adoptó el sistema de acceso abierto (open access), lo que garantiza vía libre, inmediata y sin restricciones a los textos publicados. También se permite la reproducción total o parcial de su contenido sin fines comerciales, con las condiciones de atribución y no modificación².

La revista acepta pauta publicitaria como mecanismo para complementar su financiación. Los anuncios serán posicionados en la versión impresa. El editor tiene el derecho de modificar o rechazar las solicitudes de pauta recibidas y garantizará el cumplimiento de las normas establecidas en la política editorial.

El proceso editorial se inicia con el sometimiento del manuscrito. Los autores deben disponer sus escritos para este procedimiento únicamente usando la plataforma de la revista, disponible en 
http://revista.acho.info/ojs/index.php/acho. Se debe crear una cuenta de usuario e iniciar sesión para acceder a la plataforma. Esta solicitará datos básicos del artículo y pedirá se adjunten los archivos requeridos. La carta de presentación, el manuscrito y los formatos de declaración de conflicto de interés de los autores son obligatorios, y están disponibles en http://www.icmje.org/conflicts-of-interest/3.

Una vez los autores completen el sometimiento del manuscrito en la plataforma, esta enviará a los correos electrónicos una notificación de recibido, la cual incluirá un código único que permitirá el seguimiento del texto, con lo que nos ponemos a la par de las revistas biomédicas nacionales e internacionales de gran impacto en su sometimiento de manuscritos por vía electrónica.

Se seleccionaran los manuscritos de interés de la revista por importancia de la investigación en oncología y hematología práctica, originalidad del trabajo, calidad del estudio, prioridad del trabajo; el proceso de evaluación pareada será ciego. El editor asignará mínimo dos evaluadores, uno de ellos metodológico.

La evaluación pareada permitirá tomar la decisión final: aceptado con cambios menores, aceptado con cambios mayores o rechazado. La oficina editorial notificará a los autores de la decisión, adjuntando las observaciones anónimas de los evaluadores.
Es requisito que los artículos no hayan sido publicados previamente o sometidos simultáneamente en diferentes revistas, para proteger la originalidad y evitar publicación redundante del mismo manuscrito en diferentes revistas, así como aplicar la política de embargo para evitar publicación en medios masivos o entrevistas antes de la revisión pareada y publicación $n^{4}$. La presentación oral o resumen en congresos médicos no violan las políticas editoriales.

Mediante el presente editorial, queremos informarles cómo ha sido el proceso actual de relanzamiento de la $R C H O$, las políticas editoriales, e invitar a todos los investigadores en hematología, oncología y disciplinas afines, a enviarnos sus manuscritos, para brindarles toda la colaboración a fin de que su publicación sea exitosa.

\section{Referencias}

1. International Committee of Medical Journal Editors. Recomendations the conduct, reporting, editing and publication of scholarly work in medical journals. Disponible en: http:/ wwW.ICMJE.org

2. Barreiro E. Open access: is the scientific quality of biomedical publications threatened? Arch Bronconeumol 2013;49(12):505-6

3. Drazen JM. Revisiting the commercial-academic interface. N Engl J Med 2015;372(19):1853-4.

4. Relman AS. The Ingelfinger Rule. N Engl J Med 1981;305(14):824-6. 